\title{
African Immigrant and the Struggle against Class, Racism and Xenophobic Consequences in Post-Apartheid South Africa
}

\author{
Ernest Muchu Toh \\ (LLM Stellenbosch, 2010) \\ Faculty of Business Administration, Department of Entrepreneurship, Cape \\ Peninsular University of Technology, Cape Town, South Africa (Post Graduate Student) \\ Ernest Muchu Toh, No 5 Louis Trichardt Street, Parow, 7500, Cape Town, \\ South Africa
}

\begin{abstract}
This paper brings to understanding the effects of class and racism which are manifested in xenophobic attacks against foreign blacks in South Africa. Xenophobic attacks have been persistent in the country for over the last two decade. It has amongst other things slowed the economy, particularly affected the country's relations with the African continent and tainted the image of South Africa to the entire world. These attacks turn the livelihood of Africans immigrants into a daily struggle to adapt, survive, integrate themselves and contributes to the development of the country. The article seeks to unveil the reasons South African blacks behave the way they do against their fellow Black African counterparts despite the call for African unity and solidarity also known as 'Ubuntu'. From the findings, it demonstrates that the act of xenophobia is a manifestation of effect of mindset influenced by the apartheid policy, which was based on hatred, class, race, and violence.
\end{abstract}

Keywords:- Class, race, struggle, xenophobia, South Africa, black African, immigration.

\section{INTRODUCTION}

Many scholars, government and various stakeholders have voiced and penned much literature on causes of xenophobia and its effects in South Africa as whole, yet little acknowledgement is done on class and race as projectiles to xenophobia (Adjai \& Lazaridis, 2013). Class nurses the perception one's superiority over another thereby forcing the human mind to search for reason to defend internally what distinctive characteristics distinguishes the two and metamorphoses to attacks using this traits to confront the other. Eresso, (2019:1752) confirms there has been neglect on class as a vital topic by researchers. Xenophobia is most of the times discussed in isolation from class and race thereby denying the victims the opportunity to proper diagnosis inevitably needed for synergy solution provision. The long history of apartheid in South Africa can be said to have immensely contributed to the thinking of disadvantaged black South Africans (Vora and Vora, 2004). Class and racism were the substrata of the apartheid policy having as objective the psychologically distortion of the black in many ways. One of the ways was to train the black to fight against his type also best know as 'The divide and rule policy'. Another was to train the blacks see another black as a burden. The third was the infusion into the mind of a black that nothing good can come from another black and that all good is white related (White and James, 2013:8). Business wise, South African black people were made to know they can only be consumers and note producers or entrepreneurs. And lastly, the believe that people from other Africa countries had standards of living far below those in Southern African countries where South Africa is incomparably well off. Blacks from other African countries were prone to deadly disease when compared to South African blacks. Those objectives were on their own, created a psychologically damaging and emotionally unaccommodating mind-set toward blacks. Anger, anguish, hatred, torture, violence in all forms and bloodshed were instituted during apartheid - effects of those were not eradicated when democracy was considered a replacement. Very vibrant is the legacy of apartheid in the country inclusive of a new class of manifest victimisation directed against foreign blacks who have lost their lives since 1994 till present (Charman \& Piper, 2012).

A set of views have also emerged in a bit to hypothesize the lingering phenomenon tragic in an era of African integration with South Africa deemed and leaned on by the whole continent as an eye opener and leader of economic and political salvation. In the stead of consolidating this privileged position by integrating the people of Africa, class, race, inequality and xenophobia are visible and real in the new dispensation of a democratic Republic of South Africa (Tshitereke, 1999; Gordon, 2010), which is different from the traditional, yet, inclusive of a new victimhood made up by and large of foreign blacks who recently began to realised that their hope for the spirit of 'Africanness' is illusory.

As immigrants walk on the streets of major townships in South Africa, it is common language to hear black South Africans ask questions to immigrant Africans such as :

$>$ Where are you from?

$>$ Who is your president?

$>$ How long has he been there in power?

$>$ Why are you here?

$>$ How do you see this country?

$>$ It is nice here 'nhee'?

$>$ What do you do? 
$>$ How long have you been here?

Why is everyone coming to South Africa?

$>$ Don't you miss your people?

When are you going back home?

Tired as the immigrant may be, sometimes immigrant leaves the scene faced with a possible message. Maybe this man is one of those who have never travelled out of this country, hence is vexed by the presence of immigrants. More assuring here too is the guarantee of a harmless tolerant South African against whom there is safety. Most of the questioners in these encounters are coloured and whites. Not to say the colours and whites may not possess racial attributes, it demonstrates loss of impetus to direct recourse to what was once declared, blameworthy, illegal and unacceptable.

To the coloureds, it does not make any difference staying with foreign blacks - after all we (coloureds) have been side-lined by the present black regime (Mbatha, 2017). The whites on their part have nothing to lose, yet will again emerge under neutrality with new spirits of criticism and voice should blacks discriminate against their fellow blacks, irrespective of the fact that the trend was once set by system beneficial to a majority of them. In explaining the reasons immigrants suffer xenophobic attacks from black South Africans, this paper will be organised in this following order: How do black South African view black immigrant in South Africa, the reasons why they view them the way they do and associated acts against immigrants.

\section{LITERATURE REVIEW}

\section{$>$ The concept of "Makwere kwere"}

In other encounters immigrants are not given the opportunity to be questioned. They are addressed in their new name "makwere kwere", an expression of pain and anger intended to degrade by insulting them just like American racial and apartheid protagonists thought blacks hatred by renaming them nigger and kafrir (Matsinhe, 2011). According to Mbatha (2017), black South Africans use adjectives like 'previously disadvantage' to describe their identify. While black pundits sensitive and allergic have always listened to with an inquisitive ear probing its interpretation, the insinuation of the makwere kwere postapartheid connotation towards Black Africans of other countries is true of a new look black South African. Interpretatively, "makwerekwere" means a black South African enjoys a certain leverage over the immigrant.

Each time this rhetorically biased expression is employed, immigrants are offended, , dehumanised,(Bishop, 2013; Matsinhe, 2011) demoralized and traumatised (Nyamnjoh, 2007). Diagnostically, there are two schools of thoughts on the expression. One group of people take the stance that it originates from the Sotho language "ke re" meaning "I say or I said". Another holds that it derives its origin from one of the Sotho dilates "akere moona?" meaning “do you understand?".
Though with controversial views on the meaning of what makwere kwere stands for, at least there is a general consensus in affirmation that it is not an hospitable expression. As Nyamnjoh puts it:

"Makwerekwere means different things in different contexts, but as used in South Africa and Botswana, it means not only a black person who cannot demonstrate mastery of local South African languages, but also one who hails from a country assumed to be economically and culturally backward in relation to South Africa. With reference to civilisation, the Makwerekwere would qualify as the 'homo caudatus', 'tail-men', 'cave-men', 'primitives', 'savages', 'barbarians' or 'hottentots' of modern times, those who inspired these nomenclatures in southern Africa attempting to graduate from naked savagery into the realm of citizenship. In terms of skin pigmentation, the racial hierarchy of humanity under apartheid comes into play, as Makwerekwere are usually believed to be the darkest of the dark-skinned, and to be less enlightened even when more educated than the lighterskinned South African and Batswana blacks. Makwere kwere are also thought to come from distant locations in the remotest corners of the 'Heart of Darkness' north of the Limpopo, about which South Africans and Batswana in their modernity know little, and are generally not interested to discover, except to continue the 'civilising mission' begun by European missionaries and colonialists in Southern Africa in the $17^{\text {th }}$ Century (Nyamnjoh, 2007)".

The flaws transporter by the usage of makwere kwere injures both the user and the one directed at. It is an angerand-violence accompanied expression. Stereotypically, many attacks have been registered subsequent to the usage of the expression

\section{Class as an ideology of inequality}

Europeans coming to South Africa brought with them class ideology as an instrument of dominance, control and separation. From the Anglo-Boer war (Gray, 2014) to apartheid (194) and now xenophobia can be explained under one concept, 'class'- the quest for one group recognised as superior over the other in all aspects of life. A society of class is a society of inequalities and polarisation (Durante, et al., 2017; Pickett \& Wilkinson, 2010; Jencks, 2002). Driven by this concept, the English in $1899-1902$ antagonism of the Boer was a build up from the belief they were better than the Boer, therefore were naturally entitled to certain advantages. After power was relinquished into the hands of the Boer in 1910, was also a transfer of mind-set superiority South African blacks. In 1948, apartheid was declared legal, a system meant to reduce blacks to status of less than that of animals. And in 1990, the abolition of apartheid gave birth to the black leadership and opportunity also wrongly interpreted to mean the promotion of the black race. While it might have worked in the case of the English and the Boer, South African blacks are not finding it easy to showcase their superiority because they seem not to have what it takes to do. Hence have indulged to scapegoating the vulnerable immigrants. Lives are destroyed and shops owned by African immigrants are looted same as was the 
situation of the two previous powers confiscating property, resources and power formerly belonging to the blacks.

- How immigrants are viewed by majority of South Africans in the townships

$\checkmark$ High unemployment rate: Unemployment is a major problem to the youth of South Africa. Results from Statistics South Africa (2020) reveals that from 2008 till date, the unemployment rate have been on an increase from about $22.43 \%$ to $27.32 \%$. The rise in unemployment rates coincides with the rise in xenophobic attacks in South Africa, though the actual case xenophobia was registered in 1994 (Tafira, 2017:27). Commonly said, 'an idle mine is the devil's workshop', many unemployed in South Africa live under the illusionary impression that most immigrants take away their jobs, the reason why they are not employed.

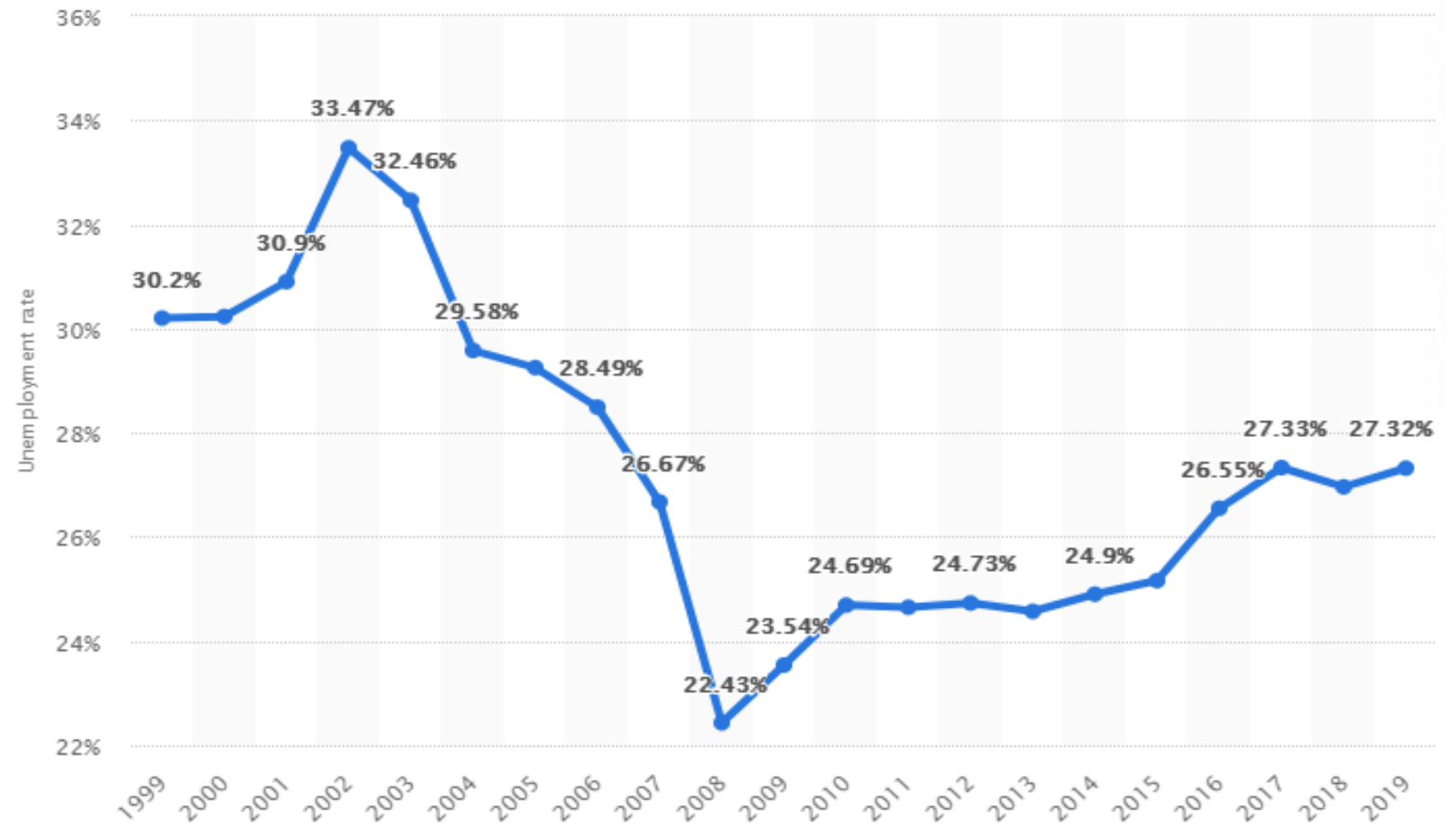

Fig 1

Unemployment rate in South Africa between 1999 2019. Source: Statistics South Africa 2020

$\checkmark$ Neo-Class and Race concept in black South Africa

The long period of subjugating of Blacks in South Africa both under the British segregation policy and the apartheid regime (Balia, 1999) planted high levels of profligacy, lost of human empathy, to a point that the arrival of democracy met South Africans with already reconfigured minds. The issues historically bequeath to black South African have not given them the momentum to systematically follow the road map leading to the averment of apartheid society. Clearly indicated early is the inherent culture of hatred class and race and xenophobia that is still 'plausibly' psyched in the minds of Black South Africans. Important to note is the interconnectedness between racism and racial manifestations and xenophobic attacks in the life of a people, nation or international communities, hence the UN remarking the dangers of these policies had this to say:

"Alarmed by the emergence and continued occurrence of racism, racial discrimination, xenophobia and related intolerance in their more subtle and contemporary forms and manifestations, as well as by other ideologies and practices based on racial or ethnic discrimination or superiority. Strongly rejecting any doctrine of racial superiority, along with theories which attempt to determine the existence of so-called distinct human races..."(Declaration et al., 2011).

Abolishing apartheid brought to an end to open ended instituted laws that manifested physically, scientifically and psychologically. Those who were freedom deprived (nonwhites) were caught up overwhelmingly by the concept of freedom. Many saw it as an opportunity to take the places of the oppressors. Having access to socio-economic facilities such as education, jobs, medical treatments, good housing and most importantly, the freedoms and inalienable rights prohibited them were anticipated more than the price of getting them.

To an average black South African, black leadership meant taking the place of rulership, becoming the boss to those in the country whereby all thinkable advantages the country possesses belong to them. Many statements are made by the black to affirm the above. For example, 
statements such as "this is our time" maybe interpreted as 'our time to be white'; 'our time to be rich'; 'our time to be in control'. Deducing from the above interpretations, being 'in control' or 'being rich' 'being white' in African context goes with subordination. Some people needs to be 'black', inferior from all standards should "whiteness" be meaningful. Such a tendency does not only suffer suspicion(Nyamnjoh, 2006) and superiority complex(Ibrahim, 2005), but extends to proving it by pointing out that the incoming black African is inferiorly different in his way of dressing, eating, talking(Harris, 2002), hence, harmful to the new South Africa's economic(Kalitanyi \& Visser, 2010) and social health. In fact, this was the mindset and expectations that orchestrated what can be termed neo-class and race in post apartheid black. McWhorter calls it 'The new black double consciousness' in which he explains that "Black American today is permeated by a new kind of double consciousness that has strayed far beyond the one Du Bois examined in 1903. To wit, a tacit sense reigns among great many black Americans today that the "authentic" black person stresses personal initiative and strength in private, but dutifully takes on the mantle of victimhood as a public face"'(McWhorter, 2003 ).

The "new black South African" (Adjai \& Lazaridis, 2013) believes that the whites exchanged their places for them, short of at least, equated them to him by the release of Mandela from the prison to the governability of the new South Africa. And a black African from another African country would not as he could not contest with a black South African no matter how bad his (South African) situation could be. As Nyamnjoh rightly puts it the "..Makwerekwere would qualify as the 'homo caudatus', 'tail-men', 'cave-men', 'primitives', 'savages', 'barbarians' or 'hottentots' of modern times" inferior to us (Nyamnjoh, 2007).

Deplorable as such a mindset might be, the truth had prevailed over the first two decades of democracy in practice that other black Africans in South Africa can knowledgeably be contributive to the South African education(Keevy, Green, \& Manik, n.d.);(Statistics South Africa, 2012) health, sports, economy and all areas of life.

Because the characteristics of racism include frustrating your dislike through compulsory attacks, black Africans are victimized. Hatred and fear do not give room for independence, objectivism and reason. The victim foreign black is aware and recognizes the dynamics of an unfriendly habit of the ones once considered brothers.

Part of the dynamics is seen in what can be called "white collar" xenophobia. In conformation with the allegation that xenophobia left the street to the office, it is no doubt an acceptable dilemma that where a dispute erupts between a South African citizen and foreign black, the black is the looser(Morris \& Bouillon, 2001; Nyamnjoh, 2006). The law enforcements have discretely disregarded applying the law when and where justice is owed the foreigner Black. The xenophobic attacks in from 2008 shows a South African Police officers laughing at a Black African that was set ablaze during attacks http://www.timeslive.co.za/local/2015/02/19/sa-s-

xenophobia-shame-burning-man-case-shut Many may argue that it was not a foreigner. However, the inhumane manifestation of literally watching another go through fire can only be done by one hardened human being who is not a first time witness of incidence of that magnitude, but also perpetrator.

In some instances, the South African Police officer will not camouflage in advising the foreigner that he has no case to win reason being that his opponent is a South African. Many will attest to numerous cases where the South African perpetrator will be arrested and few minutes later, he is released. That brings to mind the questions how many South Africans have been arrested throughout the xenophobic attacks that have beclouded South Africa from 1994 and how many have been sentenced to date? In each attack, lives were lost in cold blood felonious crimes of murder internationally unacceptable and punished as well under all national laws of all countries of the world. Evidently, there is no record of offenders of xenophobia serving a prison term unless the case of David the Mozambican whom those in the act of murder were caught flagrant delict by a white journalist and was broadcasted internally. Such prosecutions cannot be substantiated as a fight against xenophobia where arrest came as a result of fear for international inquisition and interrogation. Government luke-warmness in investigating cases of murder behind cameras helps synchronize the desire of the architect of apartheid who had invested a long time in inciting Black against Black with reality. It means apartheid is still practiced through xenophobia.

Where is then the vision of Mandela who cried out after being released from prison saying:

"During my lifetime I have dedicated myself to this struggle of the African people. I have fought against white domination, and I have fought against black domination. I have cherished the ideal of a democratic and free society in which all persons live together in harmony and with equal opportunities. It is an ideal which I hope to live for and to achieve. But if needs be, it an ideal for which I am prepared to die."?

Perhaps this speech is interpreted by South Africa Blacks to mean Blacks and whites of South Africa to the exclusion of Blacks from elsewhere in Africa. But with the support of many nations of Africa and beyond, African meant Africans. Not to disadvantage the South Africans nor share their fortune, instead, to work hand in gloves with them to build South Africa and African continent which can only be developed by Africans themselves. Reliance on any people to develop Africa has always proven abortively illusionary.

A further scenario of the prevalence of neo-class and race concept has been seen in the non-recognition of the Khoi and San whose struggle for reintegration has been double standardly ignored by politicking thereby 
maintaining what apartheid started by feeling that they are now the new whites(Robins, 2001)(Mbeki, 2003).

\section{$>$ Apartheid as precursor of Xenophobia}

As summarily illustrated above, it is clear how the era of apartheid successively went through combining intellectual, consultative politics and brutality under its three leaders namely Hendrik Verwoerd, John Vorster, P.W Botha respectively.(Giliomee,1985). As P.W Botha (also known put it "old crocodile") put it,

"For the time being, we should also engage a higher gear to make sure that Black men are separated from their women and fines imposed upon married wives who bear illegitimate children. I have a committee working on finding better methods of inciting Blacks against each other and encouraging murders among themselves. Murder cases among Blacks should bear very little punishment in order to encourage them...Ours is not a war that we can use the atomic bomb to destroy the Blacks, so we must use our intelligence to this effect"

It will be misleading therefore to ignore the past which is concomitant to present xenophobia. How this alienation, determination, and commitment are a foundation aid in better understanding the foundation that catalyzes our topic (Sandi Baai (1999): Issues of Ethics: From Past to Present). Putting it in simple terms, it was a do or die undertaking having different strategies toward one ambition. Apartheid hit its apex of cruelty under the fearless leadership of P.W. Botha, unbearable to the Blacks, degenerated into the Soweto uprising in September 1984(Giliomee, 1985). This move pushed the apartheid government to hold an emergency meeting of the South African Security Council (SCC) on 18 July 1985, together with external pressures from other African countries and the world, the outcome of which was the creation of twelve principles to neutralize "the revolutionary onslaught"(Giliomee, 1985). Black people had been pressed down and pressed out to a point fear was no longer an option. The system lost its statehood control over the Black people. The police and army became divided in opinion and neutralized by a determinant public uprising jacked by momentum from around the world. P.W. Botha has been criticized by many including the conservative of apartheid and supporters who did not avert that apartheid was a bad policy per se, but affirmed the manner in which it was put up made it unproductive. The scenario was chaotic and over split violence was the trend. People realized chaos and destruction was the medium used to orchestrate a revolution, has been using it since then.

Giliomee explained "He came well prepared to any meeting, but did not exert power like a Hendrik Verwoerd through intellectual domination or like a John Vorster, who always sought consensus at the expense of bold moves. His power was more direct and personal; he was a straight talker, tough, brutal, overpowering and, at times, thuggish, vindictive and petty. He was far from convinced of the need for fundamental political reform that would bring the black community into a common system. He opposed not only some of the proposals for reforms, but also being sucked by stealth into reforms he rejected. According to Malan, he would crush any person who was not open with him but tried to bypass him" (1985).

Turning to a democratic system of inclusiveness (Adjai \& Lazaridis, 2013; Constituion of the Republic of South Africa, 1996) in South Africa meant incomparably a lot to the blacks than to any other group. But the ramifications were yet to be dissected. Several attempts have been made from the Mandela transition time right through to the present with little results to write home on the capacity building of the black man. A lot of criticisms have been attributed to the processes undertaken during the laying of the democratic foundation of the new era South Africa and implementation of strategic programmes geared to freeing an average black South African(Co-investigator, 2013). A look at some of the processes is worth doing to help buttress our illustration why angry blacks South Africans scapegoating foreign blacks, take to xenophobic attacks.

\section{$>$ Compelling employment policies to favour South African nationals}

The contentions for xenophobia over the time are varied. Common to all are the taking away of South African girl friends by foreign men and seizure of jobs among others have been over exaggerated. Concerning issue of jobs, a plethora of measures have been put in place by the South African government to help impose fair employment to previously disadvantaged South African citizens in all the companies. Example are Employment Equity Act (Republic of South Africa, 1994), the Labour Relations Act (Republic of South Africa, 1995), the Basic Conditions of Employment Act (Republic of South Africa, 1997) and the Skills Development Act (Republic of South Africa, 1998) and Affirmative Action (South Africa, 1998 (AA) which emanated from the Employment Equity Act. Employers are compelled to absorb South Africans at all cost. The government goes as far as providing for training incentives to companies to train South Africans within their employability with skills. Regrettably, there have a slow implementation of the policy within companies. Employment remains at political and racial lines. A list of critical skills is published to ensure that foreigners are only employed in those areas where there are massive shortages of skills critical to the economy(Department of Basic Education, 2014).

In as much as it is an applauded and generally accepted worldwide endeavour that characterizes every democratic and free society(Paul, 1987), its interpretation and application is much more misleadingly to the economy where caution and care is not taken. The experience of previous countries such as Canada, Great Britain, India, Malaysia and Zimbabwe in applying the Employment Equity Act and Affirmative Action needed to be learnt to avoid repeating(Chen, 2005) the mistakes of application. Affirmative Action has often be taken to mean an opportunity to revenge the past(Tladi, 2001) rather than to correct the past through being empowered in acquiring those opportunities formerly prevented not to have. The 
question is against whom are black South Africans to exercise revenge? The obvious answer would have been against the perpetrators of apartheid whose majority are the whites. Why then are the foreign blacks exchanged for blacks? There are two reasons to allot here. First, white dominance and control is still visible and no sooner to disappear. They constitute the main private employers of the economy of the country; control the finances in addition to the natural fear(Booysen, 2007) of just attacking the white. Second is the successful legacy of divide and rule which has at all times paid colonial imperialized to incite a black man against another (Acemoglu \& Robinson, n.d.; Michalopoulos \& Papaioannou, 2010) that is still alive.

Still, those areas where foreigners co-work with South Africans, the difference remains alarming. For instance, foreigners do not stay at home "babalas" subsequent to receiving salaries; neither do they give flimsy excuses attributing to late trains or taxes very often. They are hardworking. But South Africans do all these things under the pretext it is their time irrespective of the condition. They are blind of the consequences of inconsistency at work to the employer and the economy. Foreigners have come over time to the understanding that hard work builds an individual's life and the nation. On the contrary, a black South African knows that the government must freely give everything(houses, electricity, water, education etc) as compensation for the ills apartheid committed even if the South African received free education from elsewhere during this time(Cameron, 1996; Charlton \& Kihato, 2006). That is why is common to hear a South African black ask if there is no "mahala" in isiZulu (Fiil-Flynn \& Naidoo, 2004) or "simahla" in isiXhosa languages meaning for free. Seeing a foreign black prospers in his tread in South Africa becomes a threat and continuous persecution contrarily to supposition. With all the legislation above, immigrant can not be accussed of stealing jobs from South Africans. It is not possible.

\section{METHODOLOGY}

Both the qualitative and quantitative methods were used in this research with the triangulation of data collected. The triangulations essentially assisted in fusing different methods after capturing the data in order to complements each other. The research tools and instruments utilised in the collection of data were desktop review, focus group discussions and self-administered structured questionnaires with participants inclusive of black South Africans and black African immigrants running businesses in in the Cape Town municipality.

Data was collected from some 5 different townships in Cape Town which included Delft, Dunoon, Khayelitsha, Philippi and Kraaifontein. The choice of these locations was purposefully convinced by the prevalence of xenophobic attacks on black entrepreneurs who reside or carried out their businesses in these areas. Above all, Cape town is the second highest xenophobic town with many South African blacks living under deplorable economic situations and also with a relatively high inequality gap between the rich and the poor. Put together were approximately 190 respondents. However, only 181 after data cleaning, was captured and subsequently used. Among these respondents were those who either witnessed the act of xenophobia, were victims or were schooled in the experiences of either the victim or perpetrator. Respondents of South African nationality expressed their perception about immigrant and the actual life experiences, which to them is frustrating to see someone whom you considered inferior to make the achievements you cannot make. It made the researcher to have a deeper understanding of not just the attacks on immigrants but also a far deeper inherited mind-set from the objectives of apartheid. Under the qualitative method on the one hand, the interviews were in their original form and later transcribed and analysed using content and thematic approaches. On the other hand, administered questionnaires under the quantitative data were captured and analyse by the statistician using the SPSS. In addition, quantitative statistics were used from other sources to corroborate the findings obtain from the data.

\section{DISCUSSION OF FINDINGS}

The findings in this research are classified under three main subheadings namely: the different ways South African mainly in the townships view black immigrants in South Africa; the reasons why they view immigrant in that way and the effect on the country as a whole.

\section{The fear of success on the mind of black South Africans}

As mentioned above, 181 participants came from five locations noted for xenophobic attacks in the Cape Town. In assessing the statement of fear of the successes of foreign blacks as one of the main causes of xenophobia, the following results were obtained and will be explained below. The result showed that of the 181 who responded, 103 equivalent to $61.5 \%$ strongly agreed that fear is the main motive behind xenophobic attacks. A considerable number of 53 people giving a percentage of $30.4 \%$ agreed to the statement. Combining the numbers gave 156 out of 181 South Africans from all these locations who in the affirmative. This is in confirmation with the works of many researchers notably those findings of some researchers Vander der Veer (2011:36); Bordeau (2009:2) who in the definition of xenophobia pointed the fear aspects of it and how it is one of the reasons South Africans fight against foreign blacks. In the same way. 
ISSN No:-2456-2165

\begin{tabular}{|c|c|c|c|c|c|}
\hline & & Frequency & Percent & Valid Percent & Cumulative Percent \\
\hline Valid & Agree & 103 & 61.5 & 63.9 & 63.9 \\
\hline & Agree & 53 & 30.4 & 31.6 & 95.5 \\
\hline & Disagree & 9 & 3.1 & 3.2 & 98.7 \\
\hline & Fully Strongly Disagree & 6 & 1.2 & 1.3 & 100.0 \\
\hline \multirow{2}{*}{ Missing } & Total & 171 & 96.3 & 100.0 & \\
\hline \multicolumn{2}{|c|}{ System } & 10 & 3.7 & & \\
\hline
\end{tabular}

Table 1:- Xenophobia is out of the fear that foreign blacks are progressing more than blacks South Africans

\section{Seizure of South African girlfriends from South African boys \\ In an interview with hundred women aged between 25} to 35 years dating or married foreign blacks in South Africa, with fifty of them employed having at least matric, and the other fifty having at most grade ten, it was realized that in spite of some deceitful acts that may be frustrating to some South African women caused by foreigner blacks in relation to obtaining documents from the Republic by South African women, eighty five (85\%) confessed that they were dating foreigners for the following reasons;

\section{- Numerous disappointments from South African} men. It was maintained by this number that South African black men are patriarchal and would not value a woman. The openly sleep around with their numerous girl friends, making babies without shouldering responsibility. But foreigners can love, sexually satisfying, soft and romantic and is always there when the woman needs him. This group of women had had series of disappointments from South African men when finally decided to try foreign men.

- Foreign men build value in a woman. All the women agreed that foreigners are hard working and determine to change socio economic conditions. They agreed learning a lot from the foreign blacks who train them how to do businesses and other trades different from the South Africans who will hardly corporate with the girl friend. To them having a foreign black is a thing many South African women formerly disappointed would want to do.

Ninety five per cent (95\%) accepted to have never thought of dating a foreigner and would like to go back should South African men emulate from foreigners, reasons being that of similar cultures and easy communication. Two per cent $(2 \%)$ agreed married to drug dealers. And this $2 \%$ was from the uneducated. Twenty five per cent $(25 \%)$ were married to foreigners and living together for more than ten years. All accept financially better positioned when compared to the South African men, explaining the reason why foreign guys are nicknamed 'ATM' machines because they work hard and always have money to help the lady unlike South African men who is lazy depending on the lady most of the time. Twenty five per cent (25\%) apologized for ill-treating their foreign men financially sexually. The affirmed still cheating with their former South African men.

When asked if they have ever been disappointed by a foreign men, sixteen per cent $(16 \%)$ answered yes, adding that they were the ones who abused the men. Two percent (1\%) accepted a disappointment from foreign guys after obtaining the South African ID. Thirty percent (30\%) confirmed marriage endeavours that where turned down by the girl's parents for hatred against foreign blacks.

In all the relationships, ninety percent $(90 \%)$ of the foreigners were business men owning shops or doing one form of business or the other, while ten percent $(10 \%)$ were employed. The stigma associated with dating a foreign black in the black South African community cut across all the interviewee. It comes through a lot of struggles from the family and the friends who believe that a foreign guy is primitive, carnivorous, selling drugs, wants only document and will steal your bank card.

In finding out how foreigners will obtain document through African women, ninety eight (98\%) foreigners will usually explain the need for such documents. And that many women go into agreements with the foreigners in which the foreigner agrees to do either one or more of the following: pay them, educate their child, build them a house, incorporate them into a business, pay their school fees for education or training or any other advantage that the government or South African men could not. Most of these women have in one way or the other been victimized physically or psychologically be a South African man where they turn to a foreigner as a last resort.

\section{CONCLUSION}

In a nutshell, all the issues raised above in this article culminate the paradigm shift from white dominance to black dominance in what can be termed neo-class and race in black South Africa. This does not actually mean that the black South African is originally hateful of other blacks. And if there exist such a mind toward another black, the reason is simply frustration planted by apartheid. The frustration is understood from the point of the deprivation from education, training, skills which would have advantage a South African to have full stamina and meaning to the democracy brought to him. Paradoxically, 
these attributes are found in the one once told and now thought is not deserving- the foreign black. However, it still remains a plus to the black regime for under his (lack South African) regime have other African blacks gained access to the country which was not the case with the former apartheid regime.

Nevertheless, it should be learned of the magnitude of these occurrences to be strange in Africa. Africa is known for her culture of brotherliness and solidarity especially to the a man from another country since from when Christ was recommended to be hidden in Africa.

The wake of xenophobia in South Africa is eminently inevitable. It is culturalised though inhumane, repugnant to natural justice, equity and good conscience. You can take a South Africa out of the culture of xenophobia, but xenophobia cannot be taken out of a Black South African unless the effect of apartheid is dealt with from the roots and not from the stems or branches of assumptions. As long as South African blacks continue to live in an ocean of wealth yet with dry throats - abject poverty, consciously or unconsciously, there is bound to be sporadic xenophobic attacks not on basis of crime as the policy makers and politicians will capitalize on. The protraction of xenophobic attacks from the 90 s to 2015 demonstrates that efforts geared towards eradication it are short of proper diagnosis or that the response to the diagnosis is inappropriate.

Demystifying apartheid havoc nags the black South African, most deeply because attacks on black immigrants is a way of expressing his discomfort and inability to pave the socio-economic blanked still veiling masses even after 1994. Where grievances cannot be manifest on the scapegoat black foreigner, the state will be replaced with violent destructions. Undeniable is the assurance of future insurrections demonstrating dissatisfaction that which can be interpreted as political participation marches and media. Politicians are only trying to be persuasive in their argument on who is to blame points at apartheid? Meanwhile the black South African has been given realist eyes whose mind is dry out and can only be dampened by a life that gives socio-economic belonging. Therefore as dangerous and as early as it might be to conclude mission accompli lest it is precarious on the image of the state of South Africa. Evaluation need be made on the extent to which post apartheid hope marches reality and how parameters availed to the blacks will feasibly translate same in the years ahead, without which the battle might be won, but the war still not.

\section{REFERENCES}

[1]. White, Joseph L., and James H. Cones III. Black man emerging: Facing the past and seizing a future in America. Routledge, 2013.

[2]. Vora, Jay A., and Erika Vora. "The effectiveness of South Africa's truth and reconciliation commission: perceptions of Xhosa, Afrikaner, and English South Africans." Journal of Black Studies 34, no. 3 (2004): 301-322.
[3]. Acemoglu, D., \& Robinson, J. a. (n.d.). Alfred M Arshall L Ecture Kleptocracy and Divide and-Rule: Journal of the European Economic Association, 2(May 2004), 162-192.

[4]. Adjai, C., \& Lazaridis, G. (2013). Migration, Xenophobia and New Racism in Post Apartheid South Africa. International Journal of Social Science Studies, 1(1), 192-205. http://doi.org/10.11114/ijsss.v1i1.102

[5]. Alvaredo, F., \& Atkinson, A. B. (2010). Colonial rule, apartheid and natural resources: Top incomes in South Africa, 1903-2007.

[6]. Booysen, L. (2007). Barriers to employment equity implementation and retention of blacks in management in South Africa i. South African Journal of Labour Relations, 31(1), 47-71.

[7]. Bunting, I. a N. (1994). the Higher Education Landscape.

[8]. Cameron, R. (1996). The Reconstruction and Development Programme. Journal of Theoretical Politics, 8(2), 283-294. http://doi.org/10.1177/0951692896008002009

[9]. Charlton, S., \& Kihato, C. (2006). Reaching the poor? An analysis of the influences on the evolution of South Africa's housing programme. Democracy and Delivery: Urban Policy in South Africa, 252-282.

[10]. Charman, A., \& Piper, L. (2012). Xenophobia, Criminality and Violent Entrepreneurship: Violence against Somali Shopkeepers in Delft South, Cape Town, South Africa. South African Review of Sociology, 43(3), 81-105. http://doi.org/10.1080/21528586.2012.727550

[11]. Chen, J. (2005). of Manpower, 26(6).

[12]. Co-investigator, N. (2013). No Title No Title. Journal of Chemical Information and Modeling, 53, 16891699. http://doi.org/10.1017/CBO9781107415324.004

[13]. Department of Basic Education. (2014). Government Gazette Staatskoerant. Government Gazette, 583(37230), 1-4. Retrieved from http://www.greengazette.co.za/pages/national-gazette37230-of-17-january-2014-vol-583_20140117-GGN37230-003

[14]. Fiil-Flynn, M., \& Naidoo, P. (2004). Nothing for Mahala. The Forced Installation of Prepaid Water Meters in Stretford, Extension 4, Orange Farm, Johannesburg-South Africa. In Unpublished report. Public Citizen (USA), the Anti-Privatisation Forum (South Africa) and the Coalition against Water Privatisation (South Africa). http://www. citizen. org/documents/sappm. pdf.

[15]. Giliomee, H. (1985). Great expectations : Pres . PW Botha' s Rubicon speech of 1985.

[16]. Group-Areas-Act-1950.pdf. (n.d.).

[17]. Jeremy Seekings. (2010). CENTRE FOR SOCIAL SCIENCE RESEARCH Social Surveys Unit Race, class and inequality in the South African City. CSSR Working Paper, (283).

[18]. Mailu, D. G. (1985). P. In Speech made by former South African President P.W. Botha to his Cabinet. 
[19]. Mamdani, M. (1996). Citizen and subject: Contemporary Africa and the legacy of late colonialism. Princeton University Press.

[20]. Matsinhe, D. M. (2011). Apartheid vertigo: The rise in discrimination against Africans in South Africa. Ashgate Publishing, Ltd.

[21]. Mbeki, T. (2003). Letter from the President. ANC Today, 3(45), 14-20.

[22]. Michalopoulos, S., \& Papaioannou, E. (2010). Divide and rule or the rule of the divided? The effect of national and ethnic institutions on African underdevelopment. Retrieved from http://www.voxeu.org/article/divide-and-rule-or-ruledivided-under-development-africa

[23]. Murray, C. (1987). Class, gender and the household: the developmental cycle in Southern Africa. Development and Change, 18(2), 235-249.

[24]. Paul, E. F. (1987). Equal opportunity (Vol. 5). B. Blackwell for the Social Philosophy and Policy Center, Bowling State University.

[25]. Republic of South Africa. (1996). Constitution of the Republic of South Africa, 230(38), 1-107. http://doi.org/10.1017/S0021855300011499

[26]. Robins, S. (2001). NGOs, "Bushmen" and Double Vision: The $\mathrm{p}$ khomani San Land Claim and the Cultural Politics of "Community" and "Development" in the Kalahari. Journal of Southern African Studies, 27(4), http://doi.org/10.1080/03057070120090763

[27]. Simkins, C. (2000). Income inequality and unemployment in South Africa: Facts, causes and perspectives. Bridging the Gap Between Rich and Poor in South Africa, 13.

[28]. Theissen, G. (2009). Common Past, Divided Truth: The Truth and Reconciliation Commission in South African Public Opinion. Legal Institutions and Collective Memories, 101-133.

[29]. Tladi, T. M. (2001). Chapter One Affirmative Action Chapter Two A Normative Definition of Affirmative Action, (July)

[30]. Bordeau, Jamie. Xenophobia. The Rosen Publishing Group, Inc, 2009.

[31]. Van der Veer, K., Yakushko, O., Ommundsen, R., \& Higler, L. (2011). Cross-National Measure of FearBased Xenophobia: Development of a Cumulative Scale. Psychological Reports, 109(1), 27-42. doi:10.2466/07.17.pr0.109.4.27-42.

[32]. Mbatha, S., 2017. Understanding skin colour: Exploring colourism and its articulation among black and coloured students (Doctoral dissertation, University of Cape Town).

[33]. Hashi Kenneth Tafira, H, K., 2017. Xenophobia in South Africa: A History. Springer.

[34]. Statistics South Africa, 2020. Unemployment Rate in South Africa, From 1999 - 2019

[35]. Rodriguez-Bailon, R., Bratanova, B., Willis, G.B., Lopez-Rodriguez, L., Sturrock, A. and Loughnan, S., 2017. Social class and ideologies of inequality: How they uphold unequal societies. Journal of Social Issues, 73(1), pp.99-116.
[36]. Durante, F., Tablante, C. B., \& Fiske, S. T. (2017). Poor but warm, rich but cold (and competent): Social classes in the stereotype content model. Journal of Social Issues, 73(1), 138-157.

[37]. Jencks, C. (2002). Does inequality matter? Daedalus, 131(1), 49-64

[38]. Pickett, K., \& Wilkinson, R. (2010). The spirit level: Why greater equality makes societies stronger.USA: Bloomsbury Publishing.

[39]. Gray, S.R., 2014, 'Keeping the records straight: The literary afterlife of three Boer generals', Literator 35(1), Art. \#1047, 15 pages. http://dx.doi.org/10.4102/lit.v35i1.1047 